\title{
Pathogenicity of Leptographium Species Associated with Loblolly Pine Decline
}

\author{
L. G. Eckhardt, Former Graduate Student, and J. P. Jones, Professor, Department of Plant Pathology and Crop \\ Physiology, Louisiana Agricultural Experiment Station, Louisiana State University Agricultural Center, Baton Rouge \\ 70803; and K. D. Klepzig, Entomologist, United States Department of Agriculture, United States Forest Service, \\ Southern Research Station, Pineville, LA 71360
}

\begin{abstract}
Eckhardt, L. G., Jones, J. P., and Klepzig, K. D. 2004. Pathogenicity of Leptographium species associated with loblolly pine decline. Plant Dis. 88:1174-1178.

Freshly lifted seedlings and 21-year-old trees of loblolly pine were wound-inoculated with Leptographium species recovered from the soil and/or roots of trees with loblolly decline symptoms in central Alabama. Seedlings inoculated with L. procerum in the greenhouse produced significantly fewer root initials and a smaller root mass than control seedlings. Vertical lesions produced in seedlings by $L$. serpens and $L$. terebrantis were significantly longer than in controls. Lesions produced in mature trees by $L$. serpens and $L$. lundbergii were significantly longer than in controls. Of the fungi tested, L. serpens, L. terebrantis, and L. lundbergii were the most aggressive and may pose the greatest threat to loblolly pines.
\end{abstract}

Additional keywords: root disease, root feeding insects

The associations of Leptographium spp. and root feeding insects with root disease have been demonstrated in several forest ecosystems $(11,12,15,18,37)$. In the southeastern United States, declining loblolly pines (Pinus taeda L.) appear to be more vulnerable to attack by southern pine beetle and are more likely to have Leptographium species within their root systems than are apparently healthy trees $(12,28)$. Declining loblolly pines in central Alabama exhibited extensively stained root systems and infection by Leptographium spp. (4). In particular, L. procerum (Kendrick) M.J. Wingfield, L. terebrantis S.J. Barras \& T.J. Perry, L. serpens (Goidanich) Siemaszko, and L. lundbergii Lagerberg \& Melin have recently been isolated from roots and soil near loblolly pine trees exhibiting decline symptoms in the southern United States (4). While $L$. terebrantis, $L$. procerum, and L. serpens have previously been reported from the southern United States, some reports of $L$. serpens are of doubtful authenticity (16)

$L$. terebrantis causes lesions in the phloem and induces resin-soaking of the xylem of wound-inoculated seedlings and mature trees $(9,19,36,41)$. This may be

Corresponding author: L. G. Eckhardt

E-mail: LeptoGir103@aol.com

Accepted for publication 18 May 2004.

Publication no. D-2004-0818-01R

(C) 2004 The American Phytopathological Society important when insect vectors attack the base of a living pine, but colonization of the host by the pathogen apparently is restricted to those trees attacked by the bark beetles, and then only in the vicinity of the beetle galleries (11). It also has been found that $L$. terebrantis has the ability to block water movement through stems (2931).

The disease associated with $L$. procerum is commonly known as procerum root disease or white pine root decline. In addition to being associated with this disease on white pine, $L$. procerum has been isolated from dying roots of many other conifer species in the United States $(1,11,26,39,41)$, although it has not been implicated as a primary cause of tree mortality in these other hosts. L. procerum also has been associated with growth reduction of ozone-sensitive trees (22). Trees that die of procerum root disease are often found on moist, poorly drained sites $(7,37,39,40)$, usually scattered throughout a plantation, and not in discrete infection centers. This suggests that the disease affects single trees, does not spread from infected to adjacent healthy trees through soil (24), and may involve insect vectors.

Bark beetles that colonize living conifers are frequently associated with specific fungi that are carried on the body surface or in specialized structures (32). These fungi are introduced into the tree during the insect attack, and the continued association suggests that there is a mutual benefit to the fitness of both the beetles and fungi (32). There are three hypotheses on the relationship between these fungi and the insects. One is that the insect derives some nutritional benefit from the fungi $(5,23,34,38)$, and a second is that the association might be coincidental (8). Regardless of the insects' direct benefit, several studies have suggested that the presence of blue stain fungi facilitates attacks by bark beetles $(20,21,25)$ by diminishing tree defenses (28).

$L$. procerum and $L$. terebrantis have been commonly found in the southeastern United States, but the distribution and occurrence of other Leptographium spp., such as $L$. lundbergii and $L$. serpens, are not well known. Data on the pathogenicity of these root-infecting fungi to loblolly pines are minimal, but $L$. procerum and $L$. terebrantis have been examined as possible pathogens of loblolly pine. L. terebrantis kills loblolly pine seedlings, while $L$. procerum does not $(2,3,22,27)$. In addition, $L$. terebrantis is pathogenic to several conifer species in the northeastern and western United States $(9,15,29,35,36,42,45)$.

$L$. serpens has been associated with root disease of Pinus pinea L. in Italy and $P$. radiata $\mathrm{D}$. Don and $P$. pinaster Aiton in South Africa. Wingfield et al. (43) concluded that the combined effects of feeding by insects and subsequent colonization by the fungus may result in tree death, although Zhou et al. (45) concluded in recent pathogenicity studies that $L$. serpens and $L$. lundbergii are not serious tree pathogens in South Africa. Neither fungus has yet been evaluated as a pathogen of loblolly pine.

The objectives of this study were to determine the potential of Leptographium spp. as pathogens of loblolly pine and provide information on modes of infection and root colonization by these fungi in relation to the etiology and epidemiology of loblolly pine decline. To that end, we conducted a series of inoculations of seedling and mature loblolly pines.

\section{MATERIALS AND METHODS}

Leptographium spp. used in these experiments were isolated from insect, soil, and root samples from the Talladega National Forest (Shoal Creek and Oakmulgee Ranger Districts) and Gulf State Paper Company Land in Alabama. The isolates were cultured on $2 \%$ malt extract agar 
(MEA), in the dark, for comparison to species described in Jacobs and Wingfield (16), and duplicate isolates were sent to $M$. J. Wingfield (FABI, Pretoria, South Africa) for confirmation. Representative isolates were deposited with the ATCC (accession numbers MYA-3315, MYA-3316, MYA3313, MYA-3314, and MYA-3312 for $L$. serpens, $L$. terebrantis, $L$. procerum, $L$. procerum, and $L$. lundbergii, respectively).

Inoculation studies. Three inoculation studies (one field, two greenhouse) were conducted. In the field experiment, 21year-old loblolly pines in the Palustris Experimental Forest (Johnston Tract, Kisatchie National Forest, LA) were selected for inoculation. In one greenhouse experiment, dormant and actively growing seedlings were root inoculated. In the second greenhouse experiment, seedlings were stem inoculated. All seedlings used in these experiments were supplied by the Louisiana Department of Agriculture and Forestry, Office of Forestry.

Seedling root inoculation. Roots were inoculated with an isolate of $L$. procerum isolated from soil in the root zone of declining loblolly pine (LOB-S-00-525, Talladega National Forest, Shoal Creek Ranger District, AL) or an isolate from $P$. nigra Arnold (CMW 253, Italy) provided by $\mathrm{M}$. J. Wingfield. Both isolates were grown in liquid 2\% malt extract (ME; Sigma Chemical Co., St. Louis, MO) for 2 weeks, strained, and then $100 \mathrm{~g}$ of wet mycelium was shredded in a blender with $500 \mathrm{ml}$ of $\mathrm{dH}_{2} \mathrm{O}$ for $15 \mathrm{~s}$ to form a slurry into which bare roots were dipped.

One-year-old seedlings were lifted in December 2001 for inoculation (seedlings not used immediately were kept in cold storage at $4^{\circ} \mathrm{C}$ ). One hundred and eighty seedlings were inoculated with $L$. procerum, 90 with isolate LOB-S-00-525 and 90 with isolate CMW 253, and an additional 90 served as controls. Thirty seedlings in each group were inoculated immediately, while the remaining seedlings were potted and allowed to grow for 2 and 4 weeks prior to inoculation in order to allow roots to heal from damage due to lifting. Seedlings were inoculated by dipping the roots in the viscous mycelial slurry (adapted from Hessburg and Hansen [13]); controls were dipped in mycelial-free slurry (100 g of $2 \%$ malt extract agar $+500 \mathrm{ml}$ of $\mathrm{dH}_{2} \mathrm{O}$ ). All seedlings were repotted in 2.5liter containers of Jiffy Mix Plus. The stabilized seedlings were carefully removed from the pots at 2 and 4 weeks to avoid wounding, and the potting mix was removed from the roots by washing gently with tap water prior to inoculation.

Pots were randomized in the greenhouse and watered from above to saturation three times each week for 9 weeks in two experiments (December 2001 to March 2002 and March to June 2002). Seedlings were destructively sampled $34,44,54,64$, and 74 days after inoculation, with six pots randomly sampled each time. At the time of destructive sampling, seedlings were removed from the pots, and root systems were gently washed, wrapped in a wet paper towel, and stored in plastic bags at $4^{\circ} \mathrm{C}$ for no longer than $24 \mathrm{~h}$ before examination. Dissections were made under a binocular dissecting microscope by systematically removing the bark from the root collar to the root tips. Once the bark was removed, the remaining tissue was repeatedly misted with a spray bottle containing a sterile dilute solution of distilled water and lemon juice $(80: 20 \mathrm{vol} / \mathrm{vol})$ to keep the wood moist and discourage discoloration (13). Root initials were counted, examined, and dissected to determine infection. Infection was determined by observing staining caused by the presence of pigmented hyphae in root tissue and the observation of mycelial growth with a dissecting scope. The number of infections was tallied for each seedling. After examination and dissections were completed, all roots were sectioned and plated on MEA and CSMA (MEA containing $800 \mathrm{mg}$ of cycloheximide and $200 \mathrm{mg}$ of streptomycin sulfate per liter) (14) for reisolation of the Leptographium spp. from inoculated roots and to confirm that control roots remained Leptographium free.

Seedling stem inoculation. One isolate each of L. terebrantis (LOB-R-00-805; Gulf State Paper Company Land, Tuscaloosa, AL), L. serpens (LOB-R-00-309; Talladega National Forest, Shoal Creek Ranger District, AL), L. procerum (LOB-I00-456; Talladega National Forest, Oakmulgee Ranger District, AL; Pachylobius picivorus [Coleoptera: Curculionidae] from infected tree), and $L$. lundbergii (LOB-R-00-57; Choccolocco State Park, $\mathrm{AL}$ ) was grown on $2 \%$ MEA plates. Fifty 1-year-old bare-root seedlings were potted in the greenhouse immediately after lifting and stem inoculated after 12 weeks. Seedlings were prepared for inoculation by removing needles from the lower portion of the stem and surface-disinfesting the area with $70 \%$ ethanol. A sterile razor blade was used to cut a small slit 2 to 7 $\mathrm{mm}$ long in the bark at $2 \mathrm{~cm}$ above the soil line. A 3-mm-diameter plug of MEA colonized by a given isolate was placed on the wound, wrapped with sterile cotton, moistened with sterile water, and secured with Parafilm. Each fungus was inoculated into 10 seedlings. An additional 10 seedlings were inoculated in identical fashion with disks of sterile MEA to serve as controls. All seedlings were held in a greenhouse for up to 4 months to allow symptom development. Seedlings were watered three times per week. Seedlings were examined in April 2002.

Upon examination, the portions of the stem $8 \mathrm{~cm}$ above and below the inoculation zone were excised with bark from each seedling and were placed upright for $48 \mathrm{~h}$ in a beaker containing a 1-cm-deep solu- tion of FastGreen stain (33) (FastGreen FCF; Sigma Chemical Co.) in water $(0.25$ $\mathrm{g} /$ liter) (adapted from Nevill et al. [27]). Stem sections were removed from the stain solution, and the bark plus cambium was removed above and below the inoculation point. The total length of necrotic phloem tissue was measured and recorded. Xylem conducting the stain was removed with a flamed scalpel from one side of the lesion, and the length of nonconducting, resinsoaked sapwood, delineated by absence of stain, was measured and recorded. Reisolation of the fungus was attempted on CSMA from the inoculation area, including six 1-cm-long sections above and below the observed lesion. After 7 days, the plates were examined for the presence of the respective fungi.

Tree inoculation. Twenty 21-year-old loblolly pines in the Palustris Experimental Forest (Johnston Tract, Kisatchie National Forest, LA) were selected for inoculation studies. Height and diameter at breast height (dbh) were recorded for each tree. Inoculations followed the procedure described by Klepzig (17). Each tree was wound inoculated at breast height (approximately $137 \mathrm{~cm}$ aboveground) at five equidistant points. Four points were inoculated with a test fungus grown on MEA as described above. The fifth wound was left untouched because a preliminary study showed no difference between inoculation of wounds with sterile MEA and wounds alone. Each tree was inoculated once with each of four fungi, $L$. procerum, $L$. terebrantis, L. serpens, and L. lundbergii, in random sequence. Inoculation points were prepared by smoothing the bark with a sterile machete around the stem at breast height. The inoculations were made by punching holes with a 1.9-cm-diameter leather punch into the xylem and placing a 1-cm-diameter disk of colonized MEA into each hole with a sterile spatula. Each hole was sealed with the bark plug and covered with duct tape.

Inoculations were destructively sampled after 3 weeks. The outer bark was removed with a machete to expose the phloem around the inoculation area. The phloem surface of each inoculation area was sprayed with a dilute solution of lemon juice to discourage discoloration and the lesions traced onto overhead transparencies. The total area of phloem resinosis was measured for each lesion using a digital planimeter. Reisolation of the fungus was attempted on CSMA from the inoculation area.

Statistical analysis. Lesion length and mean length of occluded tissue among treatments in the seedling stem inoculation study and the number of root initials infected and root initials present in the seedling root inoculation study were analyzed using one-way ANOVA and Proc Mixed procedures. Lesion area among treatments in the mature tree stem inoculation study 


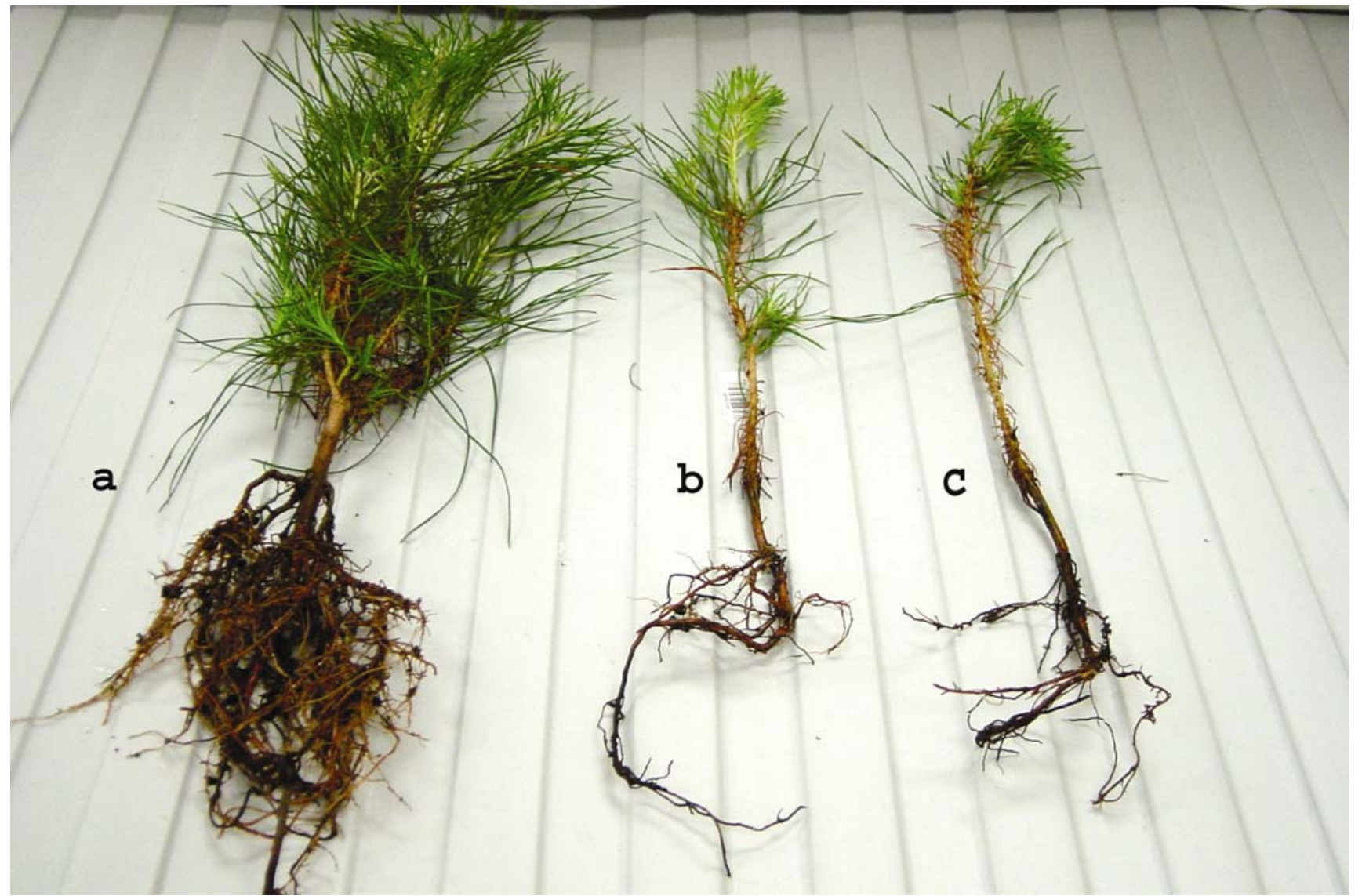

Fig. 1. Loblolly pine seedlings 72 days after root dip inoculation with A, sterile media, B, Leptographium procerum isolate CMW-253, and C, L. procerum isolate LOB-S-00-525.

Table 1. Number of root tips, percent root tips infected, percent fungal recovery, and percent mortality for loblolly pine seedlings inoculated with isolates of Leptographium procerum immediately after lifting, and after a 2- and 4-week growth period

\begin{tabular}{llcccc}
\hline $\begin{array}{l}\text { Time (wk) of } \\
\text { inoculation }\end{array}$ & Isolate & $\begin{array}{c}\text { Mean } \\
\text { root tips }^{\mathbf{y}}\end{array}$ & $\begin{array}{c}\text { Mean \% } \\
\text { infected }\end{array}$ & $\begin{array}{c}\text { Mean \% } \\
\text { fungal recovery }\end{array}$ & $\begin{array}{c}\text { Mean \% } \\
\text { mortality }\end{array}$ \\
\hline 0 & Control & $423 \mathrm{a}$ & $0 \mathrm{a}$ & $0 \mathrm{a}$ & $0 \mathrm{a}$ \\
& CMW 253 & $149 \mathrm{~b}$ & $100 \mathrm{~b}$ & $100 \mathrm{~b}$ & $0 \mathrm{a}$ \\
& LOB-S-00-525 & $161 \mathrm{~b}$ & $100 \mathrm{~b}$ & $100 \mathrm{~b}$ & $3 \mathrm{a}$ \\
& Control & $522 \mathrm{c}$ & $0 \mathrm{a}$ & $0 \mathrm{a}$ & $0 \mathrm{a}$ \\
& CMW 253 & $168 \mathrm{~b}$ & $94 \mathrm{~b}$ & $100 \mathrm{~b}$ & $7 \mathrm{a}$ \\
4 & LOB-S-00-525 & $163 \mathrm{~b}$ & $93 \mathrm{~b}$ & $100 \mathrm{~b}$ & $0 \mathrm{a}$ \\
& Control & $682 \mathrm{~d}$ & $0 \mathrm{a}$ & $0 \mathrm{a}$ & $0 \mathrm{a}$ \\
& CMW 253 & $216 \mathrm{~b}$ & $76 \mathrm{~b}$ & $100 \mathrm{~b}$ & $0 \mathrm{a}$ \\
& LOB-S-00-525 & $227 \mathrm{~b}$ & $76 \mathrm{~b}$ & $100 \mathrm{~b}$ & $3 \mathrm{a}$ \\
\hline
\end{tabular}

${ }^{y}$ Numbers followed by the same letter within a column are not significantly different at $P=0.05$, using Tukey's W test.

${ }^{z}$ Tested by chi-square.

were also analyzed using one-way ANOVA and Proc Mixed procedures. Tukey's W was used for mean separation if ANOVA indicated that there was variation among treatments. Lesion area also was analyzed for correlations with tree height and diameter at breast height (dbh) using simple linear regression. All statistical procedures were conducted on raw data using SAS (SAS Institute, 6th ed., Cary, NC).

\section{RESULTS}

Seedling root inoculation. Replication of the experiments in December and March did not significantly affect measured parameters based on Lavene's test for homogeneity of variance $\left(F_{2,537}=0.16, P=\right.$ 0.91 ), so data were combined for subsequent analysis ( $\mathrm{n}=60$ for each treatment). There was no significant difference among the sampling times (34 to 74 days) for seedlings in any treatment $\left(F_{5,102}=17.60\right.$, $P=0.691)$. Treatment significantly affected the total number of root initials produced $\left(F_{2,537}=746.10, P<0.0001\right)$ (Fig. 1) and the number of root initials infected $\left(F_{2,537}=799.06, P<0.0001\right)$ (Table 1). These parameters did not significantly differ by isolate of $L$. procerum. Four seedlings inoculated with $L$. procerum, two with isolate LOB-S-00-525 and two with isolate CMW-253, died during the course of the experiment, but none of the control seedlings died. Seventy percent of seedlings inoculated prior to planting and 2 weeks after planting had foliar symptoms (yellowing and browning) within 7 to 10 days after inoculation. However, for seedlings inoculated 4 weeks after planting, it required 14 to 20 days for $70 \%$ of the seedlings to exhibit foliar symptoms. Control seedlings had extensive candling and green foliage, with some yellowing and needle loss at the base of the stem, but no chlorotic symptoms were noted.

Root reisolations revealed that $L$. procerum colonized the xylem adjacent to the infection site. Infection sites in seedlings that were inoculated immediately following lifting were near wounded areas and areas of new growth (root initials). In contrast, the seedlings that were inoculated 2 and 4 weeks after planting had infection sites only at areas of new root initials. $L$. procerum was also reisolated from the stem area up to $2 \mathrm{~cm}$ above the soil line. Leptographium was not recovered from control seedlings.

Seedling and tree stem inoculation. Treatment significantly affected lesion length in the phloem $\left(F_{4,45}=278.97, P<\right.$ $0.0001)$ and vertical occlusion of xylem $\left(F_{4,45}=532.25, P<0.0001\right)$, but not mortality $\left(F_{4,45}=0.20, P=0.9346\right)$, in seedlings (Table 2). Eight seedlings, one control and seven inoculated with isolate $L$. 
Table 2. Length (and standard error) of lesion in phloem and linear extent of sapwood occlusion in stems of loblolly pine seedlings 4 months after inoculation with Leptographium spp.

\begin{tabular}{lcc}
\hline Fungus & Mean lesion length $\mathbf{z}(\mathbf{m m})$ & Mean occluded length $(\mathbf{m m})$ \\
\hline L. lundbergii & $34.09(4.51) \mathrm{a}$ & $52.67(4.75) \mathrm{a}$ \\
L. serpens & $30.02(1.46) \mathrm{ab}$ & $45.47(1.12) \mathrm{b}$ \\
L. terebrantis & $19.95(1.71) \mathrm{c}$ & $33.62(1.53) \mathrm{c}$ \\
L. procerum & $9.69(0.46) \mathrm{d}$ & $18.96(0.96) \mathrm{d}$ \\
Control & $7.00(0.00) \mathrm{e}$ & $11.57(0.96) \mathrm{e}$ \\
\hline
\end{tabular}

${ }^{\mathrm{z}}$ Numbers followed by the same letter within a column are not significantly different at $P=0.05$, using Tukey's W test.

Table 3. Area (and standard error) of lesion of sapwood occlusion in loblolly pine trees 3 months after inoculation with Leptographium spp.

\begin{tabular}{lc}
\hline Fungus & Mean lesion area $^{\mathbf{z}}\left(\mathbf{c m}^{\mathbf{2}}\right)$ \\
\hline L. lundbergii & $55.36(12.17) \mathrm{a}$ \\
L. serpens & $44.15(9.53) \mathrm{b}$ \\
L. terebrantis & $34.77(9.60) \mathrm{c}$ \\
L. procerum & $22.64(4.95) \mathrm{d}$ \\
Control & $4.78(0.49) \mathrm{e}$ \\
\hline
\end{tabular}

z Numbers followed by the same letter within a column are not significantly different at $P=$ 0.05 , using Tukey's W test.

serpens, died during the study. Isolates produced resin-soaked lesions that were significantly longer than those found in controls (Table 2). L. lundbergii produced significantly longer lesions than did $L$. serpens, which produced significantly longer lesions than L. terebrantis, which produced significantly longer lesions than L. procerum (Table 2). Reisolation from the inoculation site of seedlings revealed that all tested fungi colonized the xylem adjacent to the inoculation site. Leptographium spp. also were reisolated beyond the $1-\mathrm{cm}$ section adjacent to the inoculation point when the lesion or occluded tissue extended into the next $1-\mathrm{cm}$ section. None of the inoculated fungi were recovered in the $1-\mathrm{cm}$ sections beyond the last section of occluded tissue.

As in the seedling inoculations, lesions produced in mature trees by all Leptographium species were significantly larger than in the control inoculations $\left(F_{1,95}=\right.$ 107.35, $P<0.0001$ ) (Table 3). L. lundbergii produced significantly larger lesions than the other three species (Table 3). $L$. procerum produced the smallest lesions. There were no correlations between diameter at breast height (dbh range 23.4 to $29.9 \mathrm{~cm}$, mean $26.4 \mathrm{~cm}$ ) or tree height (range 6.1 to $8.5 \mathrm{~m}$, mean $7.6 \mathrm{~m}$ ) and lesion area.

\section{DISCUSSION}

Of the fungi tested, L. lundbergii and $L$. serpens caused the longest lesions in both the seedling and tree inoculations. Root systems of inoculated seedlings were severely affected by $L$. procerum. Root tips were infected, darkly stained, and necrotic. The root inoculation method presumes that $L$. procerum is a soilborne pathogen, although little evidence has been presented to support this. We did find L. procerum to be most common in the soil of decline areas, where root tip infection of mature loblolly pine occurs (4). These data suggested that $L$. procerum may be soilborne and capable of infecting root initials. Recent preliminary studies in Arkansas of dying and dead out-planted shortleaf pine seedlings revealed that $100 \%$ of the soils were infested with $L$. procerum, and dying and dead seedling roots were infected with L. procerum (L. Eckhardt and R. Menard, unpublished), suggesting that $L$. procerum may infect roots via soil. Further work is being conducted in this area.

This study establishes that the Leptoaging the stems of both seedlings and mature trees, but the causal relationship between Leptographium spp. and coniferous root diseases must be interpreted carefully. Leptographium spp. have been described as secondary pathogens introduced by bark beetles to trees that are already stressed by other organisms or environmental factors $(9,16,32,42)$. The Leptographium spp. used in this study can be introduced by root feeding bark beetles, such as Hylastes spp. $(5,42)$. They feed on apparently healthy or slightly stressed trees $(6,9,10,44)$ and may, therefore, serve as agents of injury. This suggests a complex of interacting factors (abiotic and biotic) that may impact the tree synergistically. For example, root feeding insects may attack trees stressed by abiotic factors and introduce Leptographium spp. into root systems. Lesions caused by Leptographium spp. may expand, causing increased stress on the tree, which leads to attack by other bark beetles (e.g., southern pine beetle or black turpentine beetle) or secondary pathogens. These other bark beetles carry other blue stain fungi (e.g., Ophiostoma spp.) into the stem, further contributing to stress, decline, or death of the tree. This report confirms the basic ability of Leptographium species to attack loblolly pine and suggests their possible role as pathogens involved in loblolly pine decline.

\section{LITERATURE CITED}

1. Alexander, S. A., Horner, W. E., and Lewis, K. J. 1988. Leptographium procerum as a pathogen of pines. Pages 97-112 in: Leptographium Root Diseases on Conifers. T. C. Harrington and F. W. Cobb, eds. American Phytopathological Society, St. Paul, MN. graphium spp. tested are capable of dam-
2. Cook, S. P., and Hain, F. P. 1985. Qualitative examination of the hypersensitive response of loblolly pine, Pinus taeda L., inoculated with two fungal associates of the southern pine beetle, Dendroctonus frontalis Zimmermann (Coleoptera: Scolytidae). Environ. Entomol. 14:396-400.

3. Cook, S. P., and Hain, F. P. 1988. Wound response of loblolly and shortleaf pine attacked or reattacked by Dendroctonus frontalis Zimmermann (Coleoptera: Scolytidae) or its fungal associate, Ceratocystis minor (Hedgecock) Hunt. Can. J. For. Res. 18:33-37.

4. Eckhardt, L. G. 2003. Biology and ecology of Leptographium species and their vectors as components of loblolly pine decline. Ph.D. diss. Louisiana State University, Baton Rouge.

5. Eckhardt, L. G., Goyer, R. A., Klepzig, K. D., and Jones, J. P. 2004. Interactions of Hylastes species (Coleoptera:Scolytidae) with Leptographium species associated with loblolly pine decline. J. Econ. Entomol. 97:468-474.

6. Goheen, D. J., and Cobb, F. W., Jr. 1978 Occurrence of Verticicladiella wageneri and its perfect state, Ceratocystis wageneri sp. nov., in insect galleries. Phytopathology 68:1192-1195.

7. Halambek, M. 1976. Dieback of eastern white pine (Pinus strobus L.) in cultures. Poljopr Znan. Smotra. 39:495-498.

8. Harrington, T. C. 1993. Diseases of conifers caused by Ophiostoma and Leptographium. Pages 161-172 in: Ceratocystis and Ophiostoma: Taxonomy, Ecology, and Pathogenicity. M. J. Wingfield, K. A. Seifert, and J. F. Webber, eds. American Phytopathological Society, St. Paul, MN.

9. Harrington, T. C., and Cobb, F. W., Jr. 1983. Pathogenicity of Leptographium and Verticicladiella spp. isolated from roots of western North American conifers. Phytopathology 73:596-599.

10. Harrington, T. C., Cobb, F. W., Jr., and Lownsberry, J. W. 1985. Activity of Hylastes nigrinus, a vector of Verticicladiella wageneri, in thinned stands of Douglas-fir. Can. J. For. Res. 15:519-523.

11. Harrington, T. C., and Wingfield, M. J. 1997. Other Leptographium species associated with conifer roots. Pages 9-11 in: Compendium of Conifer Diseases. E. M. Hansen and K. J. Lewis, eds. American Phytopathological Society, St. Paul, MN.

12. Hess, N. J., Otrosina, W. J., Jones, J. P., Goddard, A. J., and Walkinshaw, C. H. 1999. Reassessment of loblolly pine decline on the Oakmulgee District, Talladega National Forest, Alabama. Report No. 99-2-03. Pineville, LA: U.S. Dep. Agric., For. Serv. For. Health Prot.

13. Hessburg, P. F., and Hansen, E. M. 2000. Infection of Douglas-fir by Leptographium wageneri. Can. J. Bot. 78:1254-1261.

14. Hicks, B. R., Cobb, F. W., and Gersper, P. L. 1980. Isolation of Ceratocystis wagneri from forest soil with a selective medium. Phytopathology 70:880-883.

15. Highley, L., and Tattar, T. A. 1985. Leptographium terebrantis and black turpentine beetles associated with blue stain and mortality of black and Scots pines on Cape Cod, Massachusetts. Plant Dis. 69:528-530.

16. Jacobs, K., and Wingfield, M. J. 2001. Leptographium Species: Tree Pathogens, Insect Associates, and Agents of Blue-Stain. American Phytopathological Society, St. Paul, MN.

17. Klepzig, K. D. 1994. Interactions of stress, plant chemical defenses and subcortical insectfungal complexes in red pine decline. Ph.D. diss. University of Wisconsin, Madison.

18. Klepzig, K. D., Raffa, K. F., and Smalley, E. B. 1991. Association of an insect-fungal complex with red pine decline in Wisconsin. For. Sci. 37:1119-1139.

19. Klepzig, K. D., Smalley, E. B., and Raffa, K. F. 1996. Interactions of ecologically similar 
saprogenic fungi with healthy and abiotically stressed conifers. For. Ecol. Manag. 86:163169.

20. Krokene, P., and Solheim, H. 1996. Fungal associates of five bark beetle species colonizing Norway spruce. Can. J. For. Res. 26:21152122.

21. Kulhavy, D. L., Partridge, A. D., and Stark, R. W. 1984. Root disease and blister rust associated with bark beetles (Coleoptera: Scolytidae) in western white pine in Idaho. Environ. Entomol. 13:813-817.

22. Lackner, A. L., and Alexander, S. A. 1982. Occurrence and pathogenicity of Verticicladiella procera in Christmas tree plantations in Virginia. Plant Dis. 66:211-212.

23. Leach, J. G., Orr, L. W., and Christensen, C. 1934. The interrelationships of bark beetles and blue-staining fungi in felled Norway pine timber. J. Agric. Res. 49:315-341.

24. Lewis, K. J., Alexander, S. A., and Horner, W. E. 1987. Distribution and efficacy of propagules of Verticicladiella procera in soil. Phytopathology 77:552-556.

25. Lieutier, F., Cheniclet, C., and Gracia, J. 1989. Comparison of the defense reactions of Pinus pinaster and Pinus sylvestris to attacks by two bark beetles (Coleoptera: Scolytidae) and their associated fungi. Environ. Entomol. 18:228234.

26. Livingston, W. H., and Wingfield, M. J. 1982. First report of Verticicladiella procera on pines in Minnesota. Plant Dis. 66:260-261.

27. Nevill, R. J., Kelley, W. D., Hess, N. J., and Perry, T. J. 1995. Pathogenicity to loblolly pines of fungi recovered from trees attacked by southern pine beetles. South. J. Appl. For. 19:78-83.

28. Otrosina, W. J., Hess, N. J., Zarnoch, S. J., Perry, T. J., and Jones, J. P. 1997. Blue-stain fungi associated with roots of southern pine trees attacked by the southern pine beetle, Dendroctonus frontalis. Plant Dis. 81:942945.

29. Owen, D. R., Lindahl, K. Q., Jr., Wood, D. L., and Parmeter, J. R., Jr. 1987. Pathogenicity of fungi isolated from Dendroctonus valens, $D$. brevicomis, and D. ponderosae to ponderosa pine seedlings. Phytopathology 77:631-636.

30. Paine, T. D. 1984. Seasonal response of ponderosa pine to inoculation of the mycangial fungi from the western pine beetle. Can. J. Bot. 62:551-555.

31. Paine, T. D. 1984. Influence of the mycangial fungi of the western pine beetle on water conduction through ponderosa pine seedlings. Can. J. Bot. 62:556-558.

32. Paine, T. D., Raffa, K. F., and Harrington, T. C. 1997. Interactions among scolytid bark beetles, their associated fungi, and live host conifers. Annu. Rev. Entomol. 42:179-206.

33. Parmeter, J. R., Slaughter, G. W., Chen, M. M., Wood, D. L., and Stubbs, H. A. 1989. Single and mixed inoculations of ponderosa pine with fungal associates of Dendroctonus spp. Phytopathology 79:768-772.

34. Raffa, K. F. 1995. Bark beetles, fungi, trees and humans: Four perspectives, four agendas. Pages 7-9 in: Bark Beetle, Blue-Stain Fungi, and Conifer Defense Systems. E. Christiansen, ed. Nr. 6-95. Norwegian Forest Research Institute, AS, Norway.

35. Raffa, K. F., and Smalley, E. B. 1988. Host resistance to invasion by lower stem and root infesting insects of pine: Response to controlled inoculations with the fungal symbiont Leptographium terebrantis. Can. J. For. Res. 18:581-586.

36. Rane, K. K., and Tattar, T. A. 1987. Pathogenicity of blue-stain fungi associated with
Dendroctonus terebrantis. Plant Dis. 71:879883.

37. Shaw, C. G., and Dick, M. 1980. Verticicladiella root disease of Pinus strobus in New Zealand. Plant Dis. 64:96-98.

38. Six, D. L., and Paine, T. D. 1996. Leptographium pyrium is a mycangial fungus of Dendroctonus adjunctus. Mycologia 88:739744.

39. Towers, B. 1977. The occurrence of Verticicladiella procera in Pennsylvania-1976. Plant Dis. Rep. 61:477.

40. Weaver, M. J., and Stipes, R. J. 1983. The etiology of decline of Pinus strobus on Virginia landscapes. (Abstr.) Phytopathology 73:1348.

41. Wingfield, M. J. 1983. Association of Verticicladiella procera and Leptographium tere brantis with insects in the Lake States. Can. J. For. Res. 13:1238-1245.

42. Wingfield, M. J. 1986. Pathogenicity of Leptographium procerum and L. terebrantis on Pinus strobus seedlings and established trees. Eur. J. For. Pathol. 16:299-308.

43. Wingfield, M. J., Capretti, P., and MacKenzie, M. 1988. Leptographium spp. as pathogens of conifers, an international perspective. Pages 113-128 in: Leptographium Root Diseases on Conifers. T. C. Harrinton and F. W. Cobb, eds. American Phytopathological Society, St. Paul, $\mathrm{MN}$.

44. Witcosky, J. J., and Hansen, E. M. 1985. Rootcolonizing insects recovered from Douglas-fir in various stages of decline due to black-stain root disease. Phytopathology 75:399-402.

45. Zhou, X. D., De Beer, W., Wingfield, B. D., and Wingfield, M. J. 2002. Infection sequence and pathogenicity of Ophiostoma ips, Leptographium serpens and $L$. lundbergii to pines in South Africa. Fungal Divers. 10:229-240. 